\title{
Caveolin I and Caveolin 2 are associated with breast cancer basal-like and triple-negative immunophenotype
}

\author{
SE Elsheikh',2, AR Green', EA Rakha', RM Samaka², AA Ammar³, D Powe', JS Reis-Filho ${ }^{*, 4}$ and IO Ellis*,I \\ 'Department of Histopathology, School of Molecular Medical Sciences, Nottingham, UK; '² Department of Histopathology, Faculty of Medicine, Menoufiya \\ University, Egypt; ${ }^{3}$ Department of General Surgery, Faculty of Medicine, Cairo University, Egypt; ${ }^{4}$ The Breakthrough Breast Cancer Research Centre, \\ Institute of Cancer Research, London, UK
}

\begin{abstract}
Caveolin-I (CAVI) and caveolin 2 (CAV2) are the principal structural proteins of caveolae, sphingolipid and cholesterol-rich invaginations of the plasma membrane involved in vesicular trafficking and signal transduction. Over the recent years there has been controversy about their role in breast cancer and their suitability as markers of basal-like phenotype. Caveolin-I and CAV2 protein expression was assessed on a tissue microarray containing 880 unselected invasive breast cancer cases, by means of immunohistochemistry. Caveolin-I and CAV2 expression was observed in 13.4 and 5.9\% of all breast cancer, respectively. Their expression was strongly associated with high histological grade, lack of steroid hormone receptor positivity (ER and PR), and expression of basal markers (basal cytokeratins, P63, P-cadherin). Furthermore, there was a significant association between CAVI and CAV2 expression and basal-like phenotype. On univariate analysis only CAV2 had a prognostic impact on breast cancer-specific survival; however, this was not independent from other traditional markers on multivariate analysis. Our results demonstrate that both CAVI and CAV2 are associated with basal-like phenotype. Further studies are warranted to determine whether they play an oncogenic role in basal-like/triple-negative breast cancer development or are just surrogate markers for this subgroup.

British Journal of Cancer (2008) 99, 327-334. doi:I0.I038/sj.bjc.6604463 www.bjcancer.com
\end{abstract}

Published online 8 July 2008

(C) 2008 Cancer Research UK

Keywords: caveolin I; caveolin 2; immunohistochemistry; breast; basal-like

Caveolae are special invaginated microdomains of the plasma membrane found in the majority of mammalian cells and serve as membrane organising centres. Three members of the caveolin family (CAV1, CAV2, and CAV3) have been identified and they play a pivotal role in intracellular trafficking of cellular components and in signal transduction (Hnasko and Lisanti, 2003). Despite several studies on caveolins in cancer, especially CAV1, their role in cancer development and progression is still contentious.

Caveolin-1 and CAV2 genes map to chromosome locus $7 \mathrm{q} 31.1$ near the D7S522 genetic marker, which is a known fragile site (FRA7G) (Engelman et al, 1998; Hayashi et al, 2001; Lee et al, 2002). Caveolin-1 was first thought to have tumour suppressor properties (Razani et al, 2001a, b; Hnasko and Lisanti, 2003), based on the finding of an arguable inactivating point mutation in $C A V 1$, the silencing of $C A V 1$ gene expression by promoter hypermethylation in breast cell lines and prostate tumour samples (Engelman et al, 1999; Hurlstone et al, 1999; Cui et al, 2001) and the apparent downregulation of $C A V 1$ in breast cancer (Chen et al, 2004; Park et al, 2005). In recent years, there has been increasingly more

* Correspondence: Dr JS Reis-Filho, The Breakthrough Breast Cancer Research Centre, Institute of Cancer Research, London, SW3 6JB, UK; E-mail: Jorge.Reis-Filho@icr.ac.uk or

IO Ellis, Department of Histopathology, Nottingham City Hospital NHS Trust, Hucknall Road, Nottingham, NG5 IPB, UK.

E-mail: lan.Ellis@nottingham.ac.uk

Revised I 3 May 2008; accepted I 3 May 2008; published online 8 July 2008 coherent data to suggest that CAV1 and CAV2 may also have oncogenic properties in breast (Hurlstone et al, 1999; Pinilla et al, 2006; Van den Eynden et al, 2006; Savage et al, 2007, 2008), prostate (Yang et al, 1998; Thompson et al, 1999), bladder (Rajjayabun et al, 2001; Fong et al, 2003), oesophageal (Kato et al, 2002; Ando et al, 2007), thyroid, pancreatic, non-small cell and squamous lung cancer (Kato et al, 2004; Sunaga et al, 2004).

Despite the controversy about the distribution of CAV1 and CAV2 in normal and invasive breast cancer (Yang et al, 1998; Hurlstone et al, 1999; Chen et al, 2004; Sagara et al, 2004; Park et al, 2005; Van den Eynden et al, 2006), recent studies confirmed the preferential expression of both genes and their proteins in normal myoepithelial cells (Pinilla et al, 2006; Savage et al, 2007, 2008). Furthermore Savage et al, have recently reported high prevalence of CAV1 and CAV2 expression in basal-like breast carcinomas (Savage et al, 2007, 2008), and observed CAV1 gene amplification in a small subgroup of basal-like breast cancers (Savage et al, 2007, 2008). Moreover, these findings support Pinilla et al who described an association between CAV1 expression and sporadic basal-like breast cancers and familial BRCA1 tumours (Pinilla et al, 2006).

Our aims in this study were (1) to assess CAV1 and CAV2 prevalence in a well-characterised series of 880 cases of invasive breast carcinomas using high-throughput tissue microarray (TMA) technology and immunohistochemistry; (2) to determine whether CAV1 and CAV2 could be used as diagnostic markers to identify basal-like subtypes of invasive breast cancers, and (3) to assess if CAV1 and CAV2 have prognostic significance on the outcome of patients with invasive breast cancer. 


\section{MATERIALS AND METHODS}

\section{Patient data}

The tissue microarrays comprised a cohort of 880 consecutive breast tumours from patients diagnosed between 1986-1998 and entered into the Nottingham Tenovus Primary Breast Carcinoma Series. Histological tumour types comprised 449 invasive ductal carcinomas of no special type (NST), 182 tubular mixed carcinomas, 25 medullary carcinomas, 83 lobular carcinomas, 28 tubular carcinomas, eight mucinous carcinomas, six cribriform carcinomas, four papillary carcinomas, 29 mixed NST and lobular carcinomas, 23 mixed NST and special type carcinomas, and six miscellaneous tumours. Full details of the characterisation of the TMA and the cohort of the patients are described elsewhere (Elbauomy Elsheikh et al, 2007). Patient management was based on tumour characteristics provided by the Nottingham Prognostic Index (NPI) and hormone receptor status. Patients with an NPI score $\leqslant 3.4$ received no adjuvant therapy, those with a NPI score $>3.4$ received tamoxifen if oestrogen receptor (ER) positive: ( \pm Zoladex if pre-menopausal) or classical cyclophosphamide, methotrexate and 5-fluorouracil if ER negative and fit enough to tolerate chemotherapy (Madjd et al, 2005). Tumours were graded according to a modified Bloom-Richardson scoring system (Elston and Ellis, 1991) and size was categorised according to the TNM staging criteria (Singletary and Connolly, 2006). Nottingham Prognostic Index was calculated as previously described (Galea et al, 1992). Survival data including disease-free survival (DFS), metastasis-free survival (MFS) and breast cancer specific survival (BCSS) were maintained on a prospective basis. Disease-free survival and MFS were defined as the interval (in months) from the date of the primary surgical treatment to the first loco-regional or distant recurrence, respectively. Breast cancer-specific survival survival was taken as the time (in months) from the date of the primary surgical treatment to the time of death from breast cancer. This study was approved by the Nottingham Research Ethics Committee 2 under the title of 'Development of a molecular genetic classification of breast cancer'.

\section{Immunohistochemical staining and scoring}

Breast cancer tissue microarrays were prepared and immunohistochemically (IHC) stained for CAV1 and 2 as described previously (Abd El-Rehim et al, 2004b, 2005a; Rakha et al, 2006; Reis-Filho et al, 2006). Validation of both antibodies was performed in previous studies (Savage et al, 2007, 2008). The mouse monoclonal antibodies (2297, ref. 10 at $1: 150$ dilution and clone 65 at a dilution of $1: 50$, both BD Transduction Labs, Erembodegem, Belgium) were used for CAV1 and CAV2 staining, respectively, following microwave heat-induced antigen retrieval using DAKO antigen retrieval solution ( $\mathrm{pH}$ 6.0) (DakoCytomation, Glostrup, Denmark). Detection was achieved with the Envision kit (Dako). Negative controls comprising omission of the primary antibody and IgG-matched serum, were included in each IHC run. Caveolin-1 and CAV2 immunohistochemical distribution on tissue microarray sections was analysed by three of the authors (ER, RS \& AA), separately. Cases were classified as positive if any membranous staining (with or without cytopalsmic reactivity) was found. The analysis was performed blinded to the results of other immunohistochemical markers and patients' outcome. The immunostaining, morphometric scoring using $\mathrm{H}$-score, and dichotomous categorisation of oestrogen receptor, progesterone receptor, cytokeratin (Ck) 7/8, Ck 18, Ck 19, Ck 5/6, Ck 14, HER2, EGFR, P63, E-cadherin and P-cadherin are described elsewhere (Abd El-Rehim et al, 2004a,b, 2005b). On the basis of the expression of HER2, ER, Ck 5/6 and EGFR, tumours were classified according to the immunohistochemical panel proposed by Nielsen et al (2004) and to triple-negative phenotype (TN), which was immunohistochemically defined by the lack of expression of oestrogen receptor (ER), progesterone receptor (PR) and HER2 (HER2) (Bauer et al, 2007; Carey et al, 2007; Rakha et al, 2007).

\section{Statistical analysis}

Statistical analysis was performed using SPSS 13.0 statistical software. Median follow-up was defined as follow-up period for those patients still alive and disease-free at their latest hospital visit. All factors were used as dichotomous covariates in the statistical analysis with the exception of grade, NPI and phenotypic groups proposed by Nielsen et al (2004) that were divided into three groups. Unweighted $\kappa$ agreement coefficient test was used to assess agreement between observers of the same variables. To test whether these variables differed according to clinicopathological variables and biological markers the $\chi^{2}$ test and Fisher's exact test were used. All $P$-values were two-sided, and $P<0.05$ was considered significant. Kaplan - Meier plots were used to visualise the survival distribution. Differences in DFS, MFS and BCSS on the basis of CAV1 and CAV2 expression were estimated using log-rank test. Cox proportional hazards model was used to test the statistical independence and significance of predictors on DFS, MFS and BCSS.

\section{RESULTS}

\section{Patient clinical outcome}

Follow-up data were available for 547 out off 561 cases that showed informative data for CAV1 or CAV2. Survival time ranged from 1 to 192 months (median - 86 months, mean -81 months). During this period, a total of $78(13.9 \%)$ patients died from breast cancer. Of the available cases, $106(18.9 \%)$ cases were grade 1, $167(29.8 \%)$ cases were grade 2 , and $274(48.8 \%)$ were grade 3 . At the time of the primary diagnosis, $184(32.8 \%)$ of the patients had lymph node-positive disease, $375(66.8 \%)$ had tumour size more than $2 \mathrm{~cm}$ and distant metastases was observed in 87 cases $(15.5 \%)$.

\section{The incidence of CAV1 and CAV2 expression in invasive breast cancer}

After excluding the uninformative TMA cores, which were either lost, fragmented or did not have invasive tumour, 516 cases were analysable for CAV1 and/or CAV2: CAV1, $n=461$; CAV2, $n=410$; and both, $n=310$. Caveolin-1 positivity was detected in $13.4 \%$ whereas CAV2 was found in $5.9 \%$ of invasive breast cancer cases (Table 1) (Figure 1). Coexpression of both CAV1 and CAV2 proteins was found in only $2.5 \%$ out of 310 cases where informative data were available for both CAV1 and CAV2. A statistically significant correlation between the expression of both proteins was found $(P<0.001)$. Good agreement was found between observers regarding CAV1 and CAV2 scoring (unweighted $\kappa$ score $=0.57879)(0.4678-0.6896)$.

Table I The frequency of CAVI and CAV2 expressions in invasive breast carcinoma

\begin{tabular}{lccc}
\hline & $\begin{array}{c}\text { Number of } \\
\text { positive cases }\end{array}$ & Percentage & $\begin{array}{c}\text { Total } \\
\text { number }\end{array}$ \\
\hline CAVI & 62 & 13.4 & 461 \\
CAV2 & 24 & 5.9 & 410 \\
CAVI and CAV2 & 8 & 2.5 & 310 \\
\hline
\end{tabular}



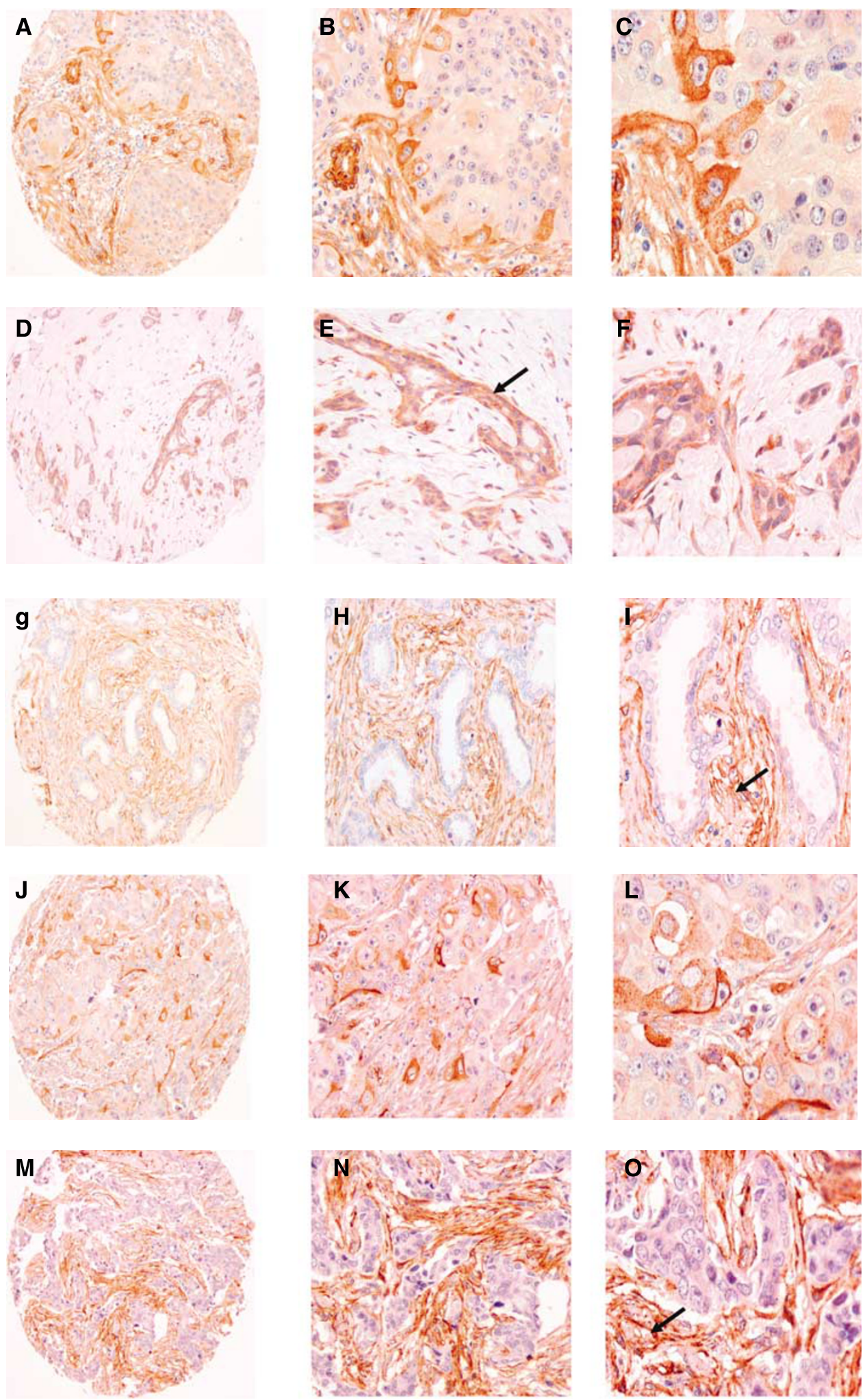

Figure I Caveolin-I and CAV2 expression in invasive duct carcinoma (IDC) of the breast. (A-C) CAVI expression in Grade 3 IDC. (D-F) CAVI positive expression in Gradel IDC the arrow in (E) point to the associated DCIS component. (G-I) CAVI negative expression in Grade I IDC. (J-L) CAV2 positive expression in Grade3 IDC. (M-O) CAV2 negative expression in Grade I IDC. The arrows in (I and $\mathbf{O})$ point to the positive stromal cells, which represent an internal positive control for CAVI and CAV2. (A, D, G, J and $\mathbf{M}$ original magnification $\times$ I00, (B, E, H, K and $\mathbf{N})$ original magnification $\times 200$; (C, F, I, L and $\mathbf{O})$ original magnification $\times 400)$. 


\section{Correlation between CAV1 and clinicopathological variables and immunohistochemical markers}

There was a significant positive correlation between CAV1 expression and high histological grade $(P=0.026)$, lack of ER and PR expression $(P<0.001$ and 0.004 , respectively). A significant inverse correlation between expression of luminal cytokeratins ( $\mathrm{Ck} 7 / 8, \mathrm{Ck} 18$, and $\mathrm{Ck} 19)$ and positivity for CAV1 was found $(P=0.003,0.001$, and 0.026 , respectively). Furthermore, there was a strong positive association between CAV1 and basal cytokeratin (Ck5/6 and Ck14) $(P=0.004$ and 0.038 , respectively) expression, as well as positivity for $\mathrm{P} 63$ and $\mathrm{P}$-cadherin $(P<0.001$ and 0.007 , respectively). These results were reflected in the phenotypic groups of breast cancer proposed by Nielsen et al (2004), where $40.5 \%$ of CAV1 positive cases had a basal-like phenotype, whereas $41.1 \%$ displayed a triple-positive phenotype (both $P<0.001$, Table 2).

\section{Correlation between CAV2 and clinicopathological variables and immunohistochemical markers}

CAV2 expression was associated with poor prognostic parameters. CAV2 expression was associated with high tumour grade $(P=0.005)$, large tumour size $(P<0.001)$ and poor Nottingham prognostic index $(P=0.017)$. A strong inverse correlation was found between lack of steroid hormone receptors ER, PgR, and AR with positive expression of CAV2 $(P<0.001,<0.001$ and 0.039 , respectively). CAV2 positive breast cancers frequently expressed basal markers, including $\mathrm{Ck} 5 / 6, \mathrm{Ck} 14, \mathrm{p} 63(P<0.001,0.001$ and $<0.001$, respectively). CAV2 was more frequently negative in those that lacked expression of luminal cytokeratins, including $\mathrm{Ck} 7 / 8$ and $\mathrm{Ck} 18 \quad(P \leqslant 0.001$ and 0.022 , respectively). An inverse correlation between CAV2 and E-cadherin expression was found $(P=0.034)$. As expected, CAV2 displayed a strong association with

Table 2 Correlation between expression of CAVI and CAV2 in tumor cells and clinicopathological and immunohistochemical markers in invasive breast cancer

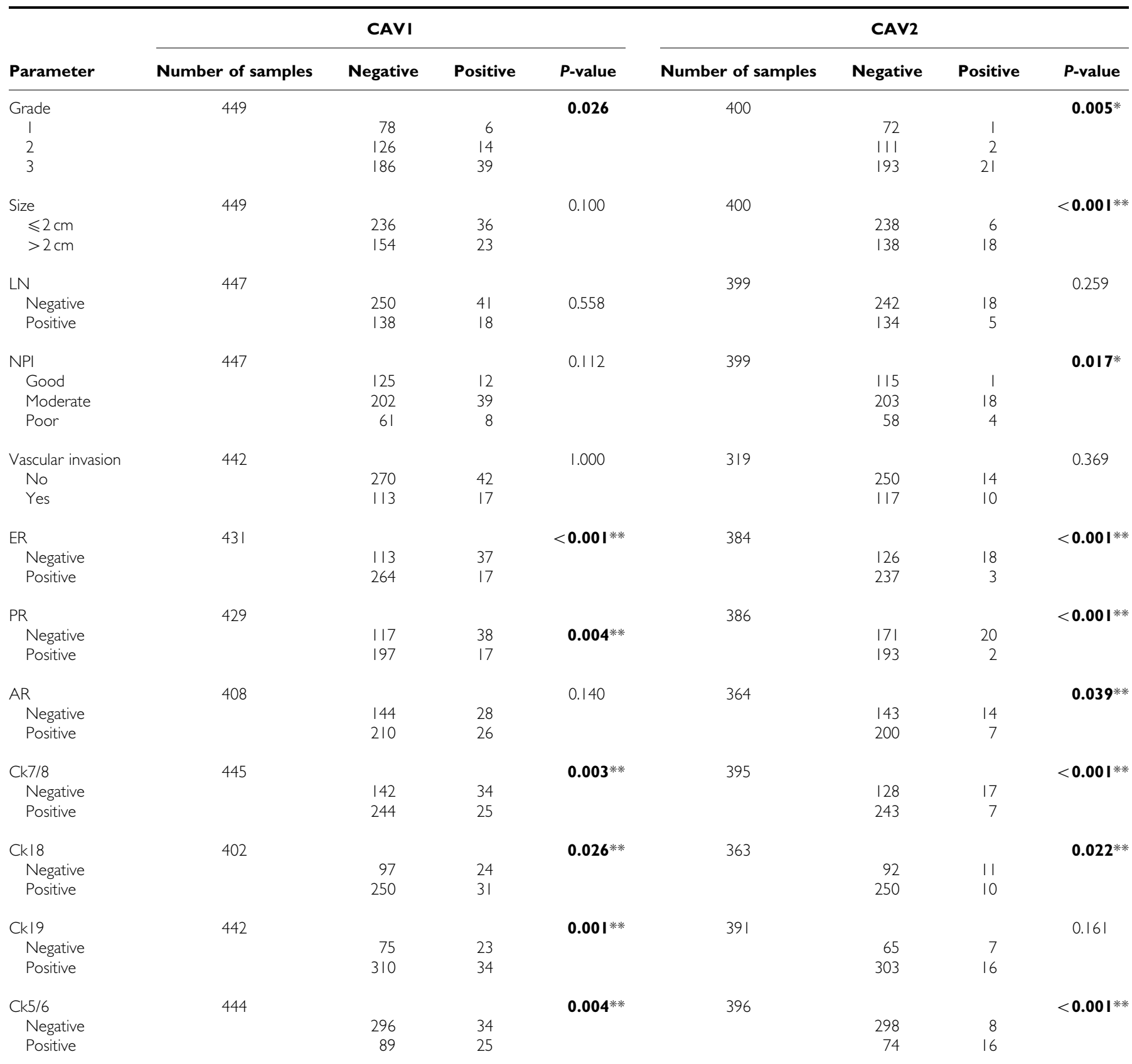


Table 2 (Continued)

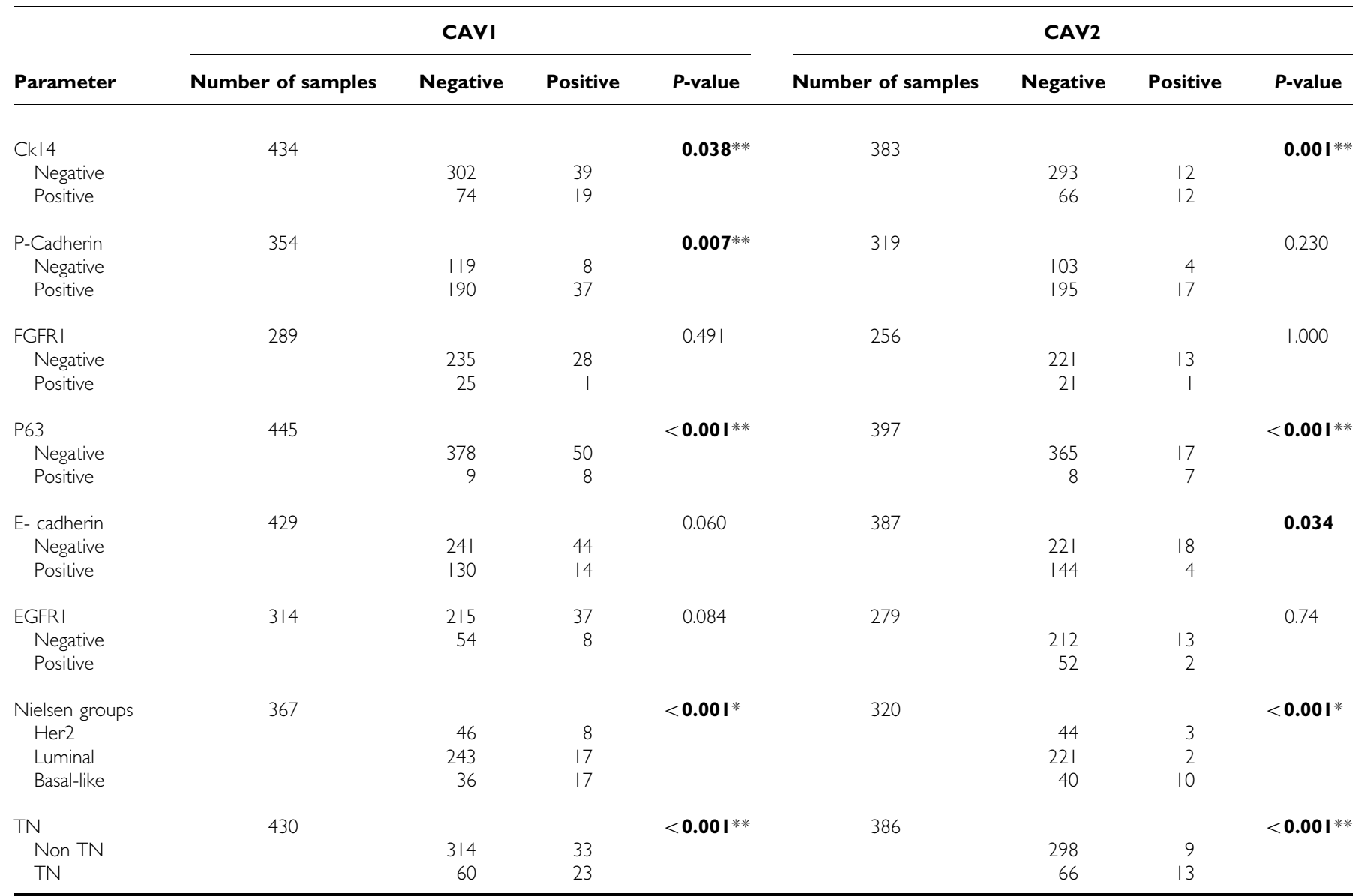

Significant $P$-values are in bold. * $\chi^{2}$ test; ***, Fisher's exact test. Nielsen groups: HER2 (HER2-positive, ER any, Ck5/6 or EGFR any), basal-like (HER2-negative, ER-negative, Ck5/6 or EGFR positive), luminal (HER2-negative, ER-positive, Ck5/6 or EGFR any). LVI, lymph vascular invasion. TN: Triple-Negative phenotype.

basal-like immunophenotype as defined by Nielsen et al.'s criteria (Nielsen et al, 2004), where $66.7 \%$ of CAV2-positive cases were of basal type whereas $58.1 \%$ displayed a triple-negative phenotype (both $P<0.001$, Table 2).

\section{CAV1 and 2 expressions in relation to patient outcome}

Kaplan-Meier survival analysis did not reveal any association between CAV1 expression and BCSS or DFS in the whole cohort. However, there was a significant association between positive CAV2 expression and shorter BCSS $(P=0.032)$ and a trend for shorter metastasis-free survival (MFS, $P=0.07$ ). Further subgrouping of the cohort revealed that in the ER-negative group of patients CAV1 expression displayed a trend for longer DFS $(P=0.069)$, whereas CAV2-positive cases showed a trend for shorter BCSS $(P=0.053)$. The only significant relation between CAV1 expression and poor outcome was observed in the low tumour grade cohort of patients (Grade 1), where positive expression of CAV1 was associated with shorter DFS $(P=0.013)$ (Figure 2). Although these results are of interest, it should be noted that this is a retrospective and exploratory analysis and the number of patients with grade 1, CAV1-positive breast cancers was rather limited. No statistically significant correlation was found between expression of CAV1, CAV2 and CAV1 and/or CAV2 and patient outcome (BCSS and DFS) in the group of chemotherapy- treated patients and when only patients with triple-negative breast cancers were analysed. On multivariate analysis, both proteins were shown not to be independent prognostic factors for DFS and BCSS.

\section{DISCUSSION}

Gene expression profiling has led to classification of breast cancers into five groups: luminal A, luminal B, basal-like, HER2 + and normal breast-like (Perou et al, 2000; Sorlie et al, 2001, 2003; van de Rijn et al, 2002; Sotiriou et al, 2003; Nielsen et al, 2004) and importantly these groups have prognostic and predictive implications. Basal-like tumours, which comprise approximately $15-20 \%$ of breast cancers, were so named because their transcriptome closely resembles that of myoepithelial/basal cells of normal breast. The majority of basal-like tumours lack ER, PgR and HER2 expression (i.e. display a triple-negative phenotype) (Nielsen et al, 2004; Rouzier et al, 2005; Banerjee et al, 2006; Livasy et al, 2006; Tan et al, 2007).

Previous studies using immunohistochemistry/immunofluorescence (Pinilla et al, 2006; Savage et al, 2007, 2008) and cDNA arrays (Jones et al, 2004; Sagara et al, 2004) have demonstrated that in ducts and lobules of normal breast, CAV1 and CAV2 expression is preferentially seen in myoepithelial and basal cells. However, caveolins 1 and 2 are also abundantly expressed in 

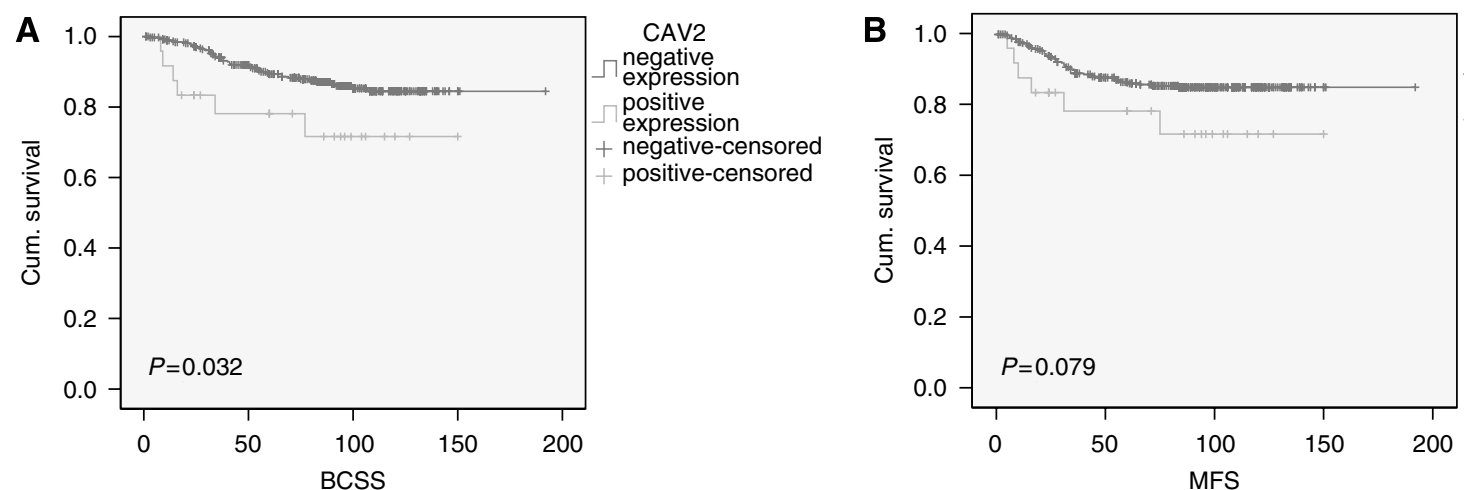

CAV2

negative

expression

positive

negative-censored

positive-censored
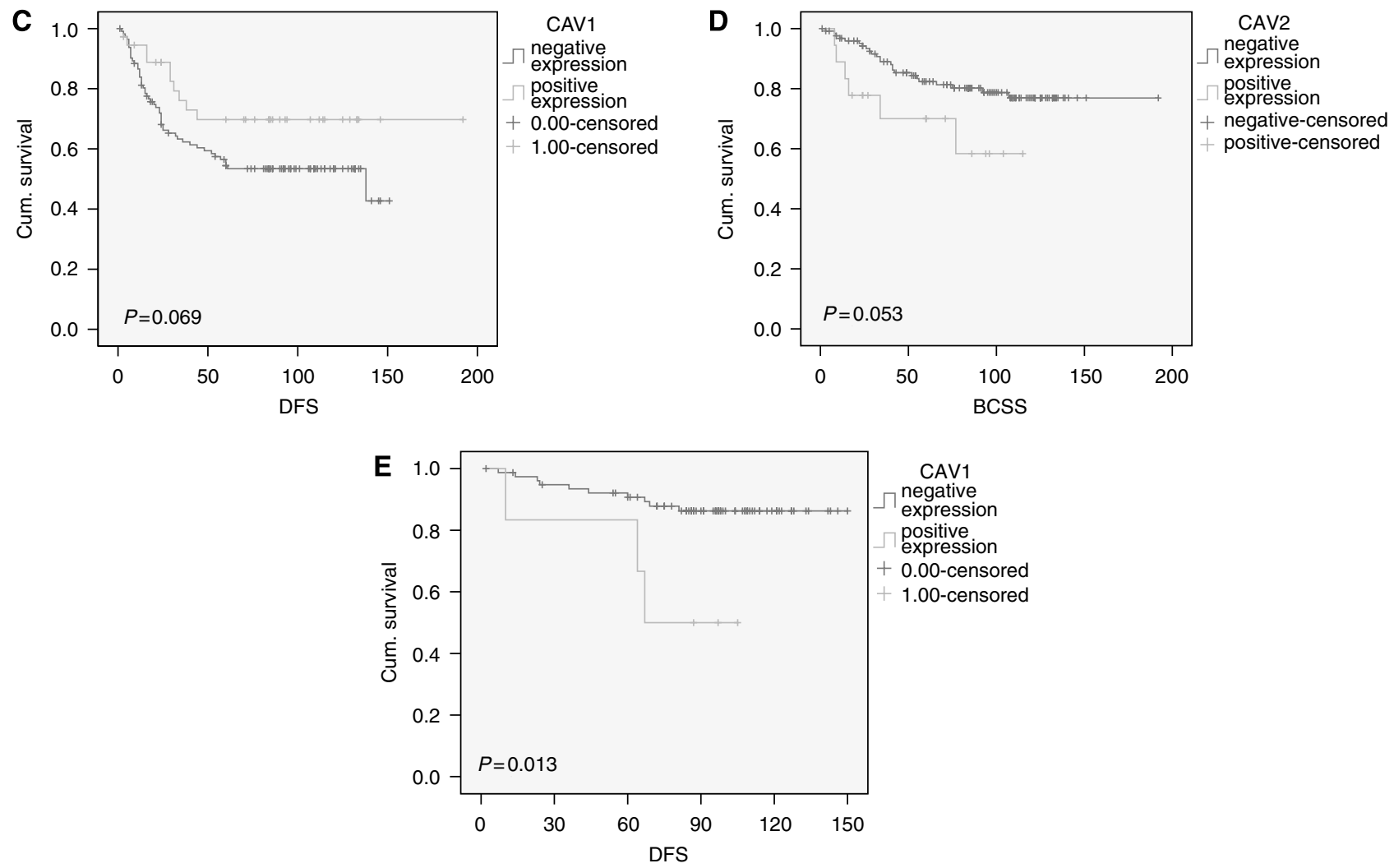

Figure 2 Kaplan-Meier plots for CAVI and CAV2 expression in invasive breast cancer. (A, B) Whole cohort regarding BCSS and MFS for CAV2. (C, D) ER-negative cohort regarding DFS and BCSS with CAVI and CAV2, respectively. (E) Low-grade cohort, the relation between CAVI and DFS.

fibroblasts, adipocytes and endothelial cells of normal breast and breast cancers (Savage et al, 2007, 2008).

Given their distribution in normal breast, we assessed the expression of CAV1 and CAV2 in a large population of invasive breast cancer to determine whether they would be preferentially expressed in the subgroup of breast carcinomas with myoepithelial/basal-like phenotype and their prognostic implications in breast cancer.

This study highlights the link between CAV1 and CAV2 with the myoepithelial/basal- and triple-negative groups of breast cancer. The evidence for this comes from the correlation seen between CAV1 and CAV2 and other conventional basal markers (Ck 14, Ck $5 / 6$, and P-cadherin). Furthermore, positive CAV1 and CAV2 expression was associated with poor prognostic parameters indicated by a poor Nottingham prognostic factor and high histological grade. Conversely, cases with positive hormone receptor status (ER and PR) and expressing luminal cytokeratins
(Ck 7/8, Ck 18 and Ck 19) showed negligible expression of CAV1 and CAV2, which is in agreement with previous studies (Hurlstone et al, 1999; Charafe-Jauffret et al, 2006; Pinilla et al, 2006; Savage et al, 2007, 2008). Therefore, it is not altogether surprising to find a significant correlation between expression of caveolins 1 and 2 and basal-like phenotype defined by Nielsen et al (2004) (40.5 and $66.7 \%$ of CAV1- and CAV2-positive cases, respectively) and the TN phenotype (41.1 and 59.1\% for CAV1- and CAV2-positive cases, respectively).

Taken together, these data suggest that expression of CAV1 and CAV2 is associated with basal-like phenotype in breast cancer. This is in accordance with previous in situ studies, which identified $C A V 1$ and $C A V 2$ genes as discriminators of the basal phenotype, and address them as one of the underlying mechanism driving CAV1 and CAV2 proteins overexpression in that group (Perou et al, 2000; Charafe-Jauffret et al, 2006; Savage et al, 2007, 2008). However, in previous gene expression profiling studies 
(Perou et al, 2000; Sorlie et al, 2001), CAV1 and CAV2 were shown to be expressed at higher levels in normal breast-like cancer. Interestingly, unlike CAV1, the level of CAV2 mRNA was also increased in the majority of basal-like cancer (Perou et al, 2000). Moreover, a PCR study suggested downregulation of CAV1 and CAV2 mRNA levels in non-microdissected breast cancer (Sagara et al, 2004). It should be noted, however, that analysis of the expression of caveolins 1 and 2 by expression array- and PCRbased methods should be interpreted with caution, given that the high levels of CAV1 and CAV2 reported in normal breast-like samples (Perou et al, 2000; Sorlie et al, 2001) may derive from stromal endothelial cells, fibroblast and adipocytes (Savage et al, 2007, 2008). Therefore, an accurate measurement of CAV1 and CAV2 mRNA levels in neoplastic cells is not possible without precise microdissection or by using in situ methods.

In this study, CAV1 expression was significantly associated with a shorter BCSS in patients with low grade invasive breast cancers whereas patients with CAV2-positive cancers had a shorter DFS. These findings are supported by previous reports showing that caveolin 1 and 2 expression is associated with highly aggressive tumours such as inflammatory breast carcinoma (Eynden, 2005), basal-like (Savage et al, 2007, 2008) and triple-negative breast carcinoma (Shack et al, 2003; Tan et al, 2007; Savage et al, 2007, 2008). Aside from breast, the association between caveolin expression and poor patient outcome was noticed in other tissue tumours (Savage et al, 2007, 2008), including prostate (Karam et al, 2007), lung ((Ho et al, 2008), and the central nervous system (Barresi et al, 2006).

The mechanism underlying the expression of CAV1 and CAV2 in breast cancer and specifically the basal-like phenotype is yet to be determined. In a small proportion of basal-like breast cancers, this seems to be driven by gene amplification (Savage et al, 2007, 2008). Moreover, hypomethylation of $C A V 1$ and $C A V 2$ promoters may be a possible cause (Engelman et al, 1999). However, the mechanism for CAV1 and CAV2 expression in basal-like cancers may stem from maintenance of a basal/myoepithelial phenotype or might be part of a transcriptomic programme of myoepithelial/basal-like differentiation, as these proteins are preferentially expressed in basal/ myoepithelial cells of normal breast.

In conclusion, our findings and those of other recently reported studies show that CAV1 and CAV2 have oncogenic properties and are associated with breast carcinomas of basal-like and triple negative phenotypes. On univariate analysis, expression of caveolins was significantly associated with high histological grade, poor Nottingham Prognostic Index and with a more aggressive clinical behaviour (i.e. CAV2 expression was associated with shorter DFS in the whole cohort and CAV1 was associated with short BCSS in the group of low grade tumours). However, on multivariate analysis, both proteins were shown not to be independent prognostic factors for DFS and BCSS. Further studies are warranted to identify whether CAV1 and CAV2 play a role in the biology of basal-like and triple-negative tumours, or if they are mere surrogate markers for basal differentiation.

\section{ACKNOWLEDGEMENTS}

We thank Emma Paish (Nottingham University hospital) and Kay Savage (Breakthrough Breast Cancer Research Centre) for their technical assistance. The ministry of high education (Egypt) for funding SE Elsheikh.

\section{REFERENCES}

Abd El-Rehim DM, Ball G, Pinder SE, Rakha E, Paish C, Robertson JF, Macmillan D, Blamey RW, Ellis IO (2005a) High-throughput protein expression analysis using tissue microarray technology of a large well-characterised series identifies biologically distinct classes of breast cancer confirming recent cDNA expression analyses. Int J Cancer 116: $340-350$

Abd El-Rehim DM, Ball G, Pinder SE, Rakha EA, Paish C, Robertson JFR, MacMillan D, Blamey RW, Ellis IO (2005b) High throughput protein expression analysis using Tissue Microarray Technology of a large well characterised series identifies biologically distinct classes of breast cancer confirming recent cDNA expression analyses. Int J Cancer 116: $340-350$

Abd El-Rehim DM, Pinder SE, Paish CE, Bell J, Blamey RW, Robertson JF, Nicholson RI, Ellis IO (2004a) Expression of luminal and basal cytokeratins in human breast carcinoma. J Pathol 203: 661-671

Abd El-Rehim DM, Pinder SE, Paish CE, Bell JA, Rampaul RS, Blamey RW, Robertson JF, Nicholson RI, Ellis IO (2004b) Expression and co-expression of the members of the epidermal growth factor receptor (EGFR) family in invasive breast carcinoma. Br J Cancer 91: $1532-1542$

Ando T, Ishiguro H, Kimura M, Mitsui A, Mori Y, Sugito N, Tomoda K, Mori R, Harada K, Katada T, Ogawa R, Fujii Y, Kuwabara Y (2007) The overexpression of caveolin-1 and caveolin-2 correlates with a poor prognosis and tumor progression in esophageal squamous cell carcinoma. Oncol Rep 18: 601-609

Banerjee S, Reis-Filho JS, Ashley S, Steele D, Ashworth A, Lakhani SR, Smith IE (2006) Basal-like breast carcinomas: clinical outcome and response to chemotherapy. J Clin Pathol 7: 729-735

Barresi V, Cerasoli S, Paioli G, Vitarelli E, Giuffre G, Guiducci G, Tuccari G, Barresi G (2006) Caveolin-1 in meningiomas: expression and clinicopathological correlations. Acta Neuropathol 112: 617-626

Bauer KR, Brown M, Cress RD, Parise CA, Caggiano V (2007) Descriptive analysis of estrogen receptor (ER)-negative, progesterone receptor (PR)negative, and HER2-negative invasive breast cancer, the so-called triplenegative phenotype: a population-based study from the California cancer Registry. Cancer 109: 1721-1728

Carey LA, Dees EC, Sawyer L, Gatti L, Moore DT, Collichio F, Ollila DW, Sartor CI, Graham ML, Perou CM (2007) The triple negative paradox: primary tumor chemosensitivity of breast cancer subtypes. Clin Cancer Res 13: $2329-2334$

Charafe-Jauffret E, Ginestier C, Monville F, Finetti P, Adelaide J, Cervera N, Fekairi S, Xerri L, Jacquemier J, Birnbaum D, Bertucci F (2006) Gene expression profiling of breast cell lines identifies potential new basal markers. Oncogene 25: 2273-2284

Chen ST, Lin SY, Yeh KT, Kuo SJ, Chan WL, Chu YP, Chang JG (2004) Mutational, epigenetic and expressional analyses of caveolin-1 gene in breast cancers. Int J Mol Med 14: 577-582

Cui J, Rohr LR, Swanson G, Speights VO, Maxwell T, Brothman AR (2001) Hypermethylation of the caveolin-1 gene promoter in prostate cancer. Prostate 46: $249-256$

Elbauomy Elsheikh S, Green AR, Lambros MB, Turner NC, Grainge MJ, Powe D, Ellis IO, Reis-Filho JS (2007) FGFR1 amplification in breast carcinomas: a chromogenic in situ hybridisation analysis. Breast Cancer Res 9: R23

Elston CW, Ellis IO (1991) Pathological prognostic factors in breast cancer. I. The value of histological grade in breast cancer: experience from a large study with long-term follow-up. Histopathology 19: 403-410

Engelman JA, Zhang XL, Lisanti MP (1998) Genes encoding human caveolin-1 and -2 are co-localized to the D7S522 locus (7q31.1) a known fragile site (FRA7G) that is frequently deleted in human cancers. FEBS Lett 436: $403-410$

Engelman JA, Zhang XL, Lisanti MP (1999) Sequence and detailed organization of the human caveolin-1 and -2 genes located near the D7S522 locus (7q31.1) Methylation of a CpG island in the $5^{\prime}$ promoter region of the caveolin-1 gene in human breast cancer cell lines. FEBS Lett 448: $221-230$

Eynden VD (2005) Overexpression of caveolin-1 and -2 in cell lines and in human samples of inflammatory breast cancer. Breast Cancer Res Treat 95: $219-228$

Fong A, Garcia E, Gwynn L, Lisanti MP, Fazzari MJ, Li M (2003) Expression of caveolin-1 and caveolin-2 in urothelial carcinoma of the urinary 
bladder correlates with tumor grade and squamous differentiation. Am J Clin Pathol 120: $93-100$

Galea MH, Blamey RW, Elston CE, Ellis IO (1992) The Nottingham Prognostic Index in primary breast cancer. Breast Cancer Res Treat 22: 207-219

Hayashi K, Matsuda S, Machida K, Yamamoto T, Fukuda Y, Nimura Y, Hayakawa T, Hamaguchi M (2001) Invasion activating caveolin-1 mutation in human scirrhous breast cancers. Cancer Res 61: 2361-2364

Hnasko R, Lisanti MP (2003) The biology of caveolae: lessons from caveolin knockout mice and implications for human disease. Mol Interv 3: $445-464$

Ho CC, Kuo SH, Huang PH, Huang HY, Yang CH, Yang PC (2008) Caveolin-1 expression is significantly associated with drug resistance and poor prognosis in advanced non-small cell lung cancer patients treated with gemcitabine-based chemotherapy. Lung Cancer 59: 105-110

Hurlstone AF, Reid G, Reeves JR, Fraser J, Strathdee G, Rahilly M, Parkinson EK, Black DM (1999) Analysis of the CAVEOLIN-1 gene at human chromosome $7 \mathrm{q} 31.1$ in primary tumours and tumour-derived cell lines. Oncogene 18: $1881-1890$

Jones C, Mackay A, Grigoriadis A, Cossu A, Reis-Filho JS, Fulford L, Dexter T, Davies S, Bulmer K, Ford E, Parry S, Budroni M, Palmieri G, Neville AM, O'Hare MJ, Lakhani SR (2004) Expression profiling of purified normal human luminal and myoepithelial breast cells: identification of novel prognostic markers for breast cancer. Cancer Res 64: 3037-3045

Karam JA, Lotan Y, Roehrborn CG, Ashfaq R, Karakiewicz PI, Shariat SF (2007) Caveolin-1 overexpression is associated with aggressive prostate cancer recurrence. Prostate 67: 614-622

Kato K, Hida Y, Miyamoto M, Hashida H, Shinohara T, Itoh T, Okushiba S, Kondo S, Katoh H (2002) Overexpression of caveolin-1 in esophageal squamous cell carcinoma correlates with lymph node metastasis and pathologic stage. Cancer 94: 929-933

Kato T, Miyamoto M, Kato K, Cho Y, Itoh T, Morikawa T, Okushiba S, Kondo S, Ohbuchi T, Katoh H (2004) Difference of caveolin-1 expression pattern in human lung neoplastic tissue. Atypical adenomatous hyperplasia, adenocarcinoma and squamous cell carcinoma. Cancer Lett 214: $121-128$

Lee H, Park DS, Razani B, Russell RG, Pestell RG, Lisanti MP (2002) Caveolin-1 mutations (P132L and null) and the pathogenesis of breast cancer: caveolin-1 (P132L) behaves in a dominant-negative manner and caveolin-1 (-/-) null mice show mammary epithelial cell hyperplasia. Am J Pathol 161: $1357-1369$

Livasy CA, Karaca G, Nanda R, Tretiakova MS, Olopade OI, Moore DT, Perou CM (2006) Phenotypic evaluation of the basal-like subtype of invasive breast carcinoma. Mod Pathol 19: 264-271

Madjd Z, Parsons T, Watson NF, Spendlove I, Ellis I, Durrant LG (2005) High expression of Lewis $y / b$ antigens is associated with decreased survival in lymph node negative breast carcinomas. Breast Cancer Res 7: R780 - R787

Nielsen TO, Hsu FD, Jensen K, Cheang M, Karaca G, Hu Z, Hernandez-Boussard T, Livasy C, Cowan D, Dressler L, Akslen LA, Ragaz J, Gown AM, Gilks CB, van de Rijn M, Perou CM (2004) Immunohistochemical and clinical characterization of the basal-like subtype of invasive breast carcinoma. Clin Cancer Res 10: 5367-5374

Park SS, Kim JE, Kim YA, Kim YC, Kim SW (2005) Caveolin-1 is downregulated and inversely correlated with HER2 and EGFR expression status in invasive ductal carcinoma of the breast. Histopathology 47: $625-630$

Perou CM, Sorlie T, Eisen MB, van de Rijn M, Jeffrey SS, Rees CA, Pollack JR, Ross DT, Johnsen H, Akslen LA, Fluge O, Pergamenschikov A, Williams C, Zhu SX, Lonning PE, Borresen-Dale AL, Brown PO, Botstein D (2000) Molecular portraits of human breast tumours. Nature 406: $747-752$

Pinilla SM, Honrado E, Hardisson D, Benitez J, Palacios J (2006) Caveolin-1 expression is associated with a basal-like phenotype in sporadic and hereditary breast cancer. Breast Cancer Res Treat 99: 85-90

Rajjayabun PH, Garg S, Durkan GC, Charlton R, Robinson MC, Mellon JK (2001) Caveolin-1 expression is associated with high-grade bladder cancer. Urology 58: 811-814

Rakha EA, El-Sayed ME, Green AR, Lee AH, Robertson JF, Ellis IO (2007) Prognostic markers in triple-negative breast cancer. Cancer 109: 25-32

Rakha EA, Putti TC, Abd El-Rehim DM, Paish C, Green AR, Powe DG, Lee AH, Robertson JF, Ellis IO (2006) Morphological and immunophenotypic analysis of breast carcinomas with basal and myoepithelial differentiation. J Pathol 208: 495-506
Razani B, Engelman JA, Wang XB, Schubert W, Zhang XL, Marks CB, Macaluso F, Russell RG, Li M, Pestell RG, Di Vizio D, Hou Jr H, Kneitz B, Lagaud G, Christ GJ, Edelmann W, Lisanti MP (2001a) Caveolin-1 null mice are viable but show evidence of hyperproliferative and vascular abnormalities. J Biol Chem 276: $38121-38138$

Razani B, Schlegel A, Liu J, Lisanti MP (2001b) Caveolin-1, a putative tumour suppressor gene. Biochem Soc Trans 29: 494-499

Reis-Filho JS, Savage K, Lambros MB, James M, Steele D, Jones RL, Dowsett M (2006) Cyclin D1 protein overexpression and CCND1 amplification in breast carcinomas: an immunohistochemical and chromogenic in situ hybridisation analysis. Mod Pathol 19: 999-1009

Rouzier R, Perou CM, Symmans WF, Ibrahim N, Cristofanilli M, Anderson K, Hess KR, Stec J, Ayers M, Wagner P, Morandi P, Fan C, Rabiul I, Ross JS, Hortobagyi GN, Pusztai L (2005) Breast cancer molecular subtypes respond differently to preoperative chemotherapy. Clin Cancer Res 11: 5678-5685

Sagara Y, Mimori K, Yoshinaga K, Tanaka F, Nishida K, Ohno S, Inoue H, Mori M (2004) Clinical significance of Caveolin-1, Caveolin-2 and HER2/ neu mRNA expression in human breast cancer. Br J Cancer 91: 959-965

Savage K, Lambros MB, Robertson D, Jones RL, Jones C, Mackay A, James M, Hornick JL, Pereira EM, Milanezi F, Fletcher CD, Schmitt FC, Ashworth A, Reis-Filho JS (2007) Caveolin 1 is overexpressed and amplified in a subset of basal-like and metaplastic breast carcinomas: a morphologic, ultrastructural, immunohistochemical, and in situ hybridization analysis. Clin Cancer Res 13: 90-101

Savage K, Leung S, Todd SK, Brown LA, Jones RL, Robertson D, James M, Parry S, Rodrigues Pinilla SM, Huntsman D, Reis-Filho JS (2008) Distribution and significance of caveolin 2 expression in normal breast and invasive breast cancer: an immunofluorescence and immunohistochemical analysis. Breast Cancer Res Treat 110: 245-256

Shack S, Wang XT, Kokkonen GC, Gorospe M, Longo DL, Holbrook N] (2003) Caveolin-induced activation of the phosphatidylinositol 3-kinase/ Akt pathway increases arsenite cytotoxicity. Mol Cell Biol 23: 2407-2414

Singletary SE, Connolly JL (2006) Breast Cancer Staging: Working With the Sixth Edition of the AJCC Cancer Staging Manual. CA Cancer J Clin 56: $37-47$

Sorlie T, Perou CM, Tibshirani R, Aas T, Geisler S, Johnsen H, Hastie T, Eisen MB, van de Rijn M, Jeffrey SS, Thorsen T, Quist H, Matese JC, Brown PO, Botstein D, Eystein Lonning P, Borresen-Dale AL (2001) Gene expression patterns of breast carcinomas distinguish tumor subclasses with clinical implications. Proc Natl Acad Sci USA 98: 10869-10874

Sorlie T, Tibshirani R, Parker J, Hastie T, Marron JS, Nobel A, Deng S, Johnsen H, Pesich R, Geisler S, Demeter J, Perou CM, Lonning PE, Brown PO, Borresen-Dale AL, Botstein D (2003) Repeated observation of breast tumor subtypes in independent gene expression data sets. Proc Natl Acad Sci USA 100: $8418-8423$

Sotiriou C, Neo SY, McShane LM, Korn EL, Long PM, Jazaeri A, Martiat P, Fox SB, Harris AL, Liu ET (2003) Breast cancer classification and prognosis based on gene expression profiles from a population-based study. Proc Natl Acad Sci USA 100: 10393-10398

Sunaga N, Miyajima K, Suzuki M, Sato M, White MA, Ramirez RD, Shay JW, Gazdar AF, Minna JD (2004) Different roles for caveolin-1 in the development of non-small cell lung cancer versus small cell lung cancer. Cancer Res 64: 4277-4285

Tan DS, Marchio C, Jones RL, Savage K, Smith IE, Dowsett M, Reis-Filho JS (2007) Triple negative breast cancer: molecular profiling and prognostic impact in adjuvant anthracycline-treated patients. Breast Cancer Res Treat; epub ahead of print: DOI: 10.1007/s10549-007-9756-8

Thompson TC, Timme TL, Li L, Goltsov A (1999) Caveolin-1, a metastasisrelated gene that promotes cell survival in prostate cancer. Apoptosis 4: $233-237$

van de Rijn M, Perou CM, Tibshirani R, Haas P, Kallioniemi O, Kononen J, Torhorst J, Sauter G, Zuber M, Kochli OR, Mross F, Dieterich H, Seitz R, Ross D, Botstein D, Brown P (2002) Expression of cytokeratins 17 and 5 identifies a group of breast carcinomas with poor clinical outcome. Am J Pathol 161: $1991-1996$

Van den Eynden GG, Van Laere SJ, Van der Auwera I, Merajver SD, Van Marck EA, van Dam P, Vermeulen PB, Dirix LY, van Golen KL (2006) Overexpression of caveolin-1 and -2 in cell lines and in human samples of inflammatory breast cancer. Breast Cancer Res Treat 95: 219-228

Yang G, Truong LD, Timme TL, Ren C, Wheeler TM, Park SH, Nasu Y, Bangma CH, Kattan MW, Scardino PT, Thompson TC (1998) Elevated expression of caveolin is associated with prostate and breast cancer. Clin Cancer Res 4: 1873-1880 